DOI: $10.34185 / 1991-7848.2019 .01 .08$

УДК 004.942 : 621.74.04:621.746.6

Т.В. Селівьорстова, В.Ю. Селівьорстов

\title{
МАТЕМАТИЧНА МОДЕЛЬ ФОРМУВАННЯ ДВОФАЗНОЇ ЗОНИ ВИЛИВКА ІЗ АЛЮМІНІЄВОГО СПЛАВУ ЕВТЕКТИЧНОГО СКЛАДУ, ЩО ТВЕРДНЕ ПРИ НАРОСТАЮЧОМУ ГАЗОВОМУ ТИСКУ
}

\begin{abstract}
Аналіз теплових полів дозволяє отримати достовірну інформацію про розташування теплових вузлів, областей з недостатньюю або надмірною динамікою затвердіння, але при цьому розрахунок усадкової раковини та макрошпаристості проводиться на підставі критеріальних оцінок. Шпаристість є одним з основних дефектів виливків, що призводить до зниження механічних властивостей. Даний дефект виникає в результаті недостатнього або утрудненого живлення двофазної зони, тому актуальною проблемою $\epsilon$ розробка математичних моделей формування двофазної зони виливків, що тверднуть в умовах наростаючого газового тиску, зокрема виливків із алюмінієвих сплавів евтектичного складу, що є одними з найпоширеніших для виготовлення фасонного литва. Запропонована математична модель живлення двофазної зони металевих виливків, що твердіють під впливом регульованого газового тиску базується на термодинамічній клітинно-автоматній математичній моделі для опису металургійних процесів 3 фазовими переходами, що забезпечує коректний облік зміни термодинамічних характеристик металів при затвердінні. Модель живлення двофазної зони дозволяє забезпечити коректне врахування регульованого газового тиску в системі виливок-форма й може бути масштабована на двомірний, тривимірний простір. Наведені результати моделювання процесу живлення двохфазної зони виливку з алюмінієвого сплаву евтектичного складу. Отримані залежності кількості рідкої фази в локальних об'ємах в двофазній зоні.
\end{abstract}

Ключові слова: математична модель, теплоперенос, масоперенос, фільтрація, усадка, алюмінієвий сплав, евтектика.

\section{Вступ}

Відомо, що математичне моделювання процесу затвердіння виливка $\epsilon$ невід'ємною частиною розробки ливарних технологій. При цьому, застосування імітаційного комп'ютерного експерименту на ранньому етапі відпрацьовування технології лиття дозволяє усунути або максимально відкоригувати можливі дефекти в найкоротший термін. На даний момент ринок систем комп'ютерного моделювання ливарних процесів насичений програмними засобами, що добре зарекомендували себе (MAGMASOFT, LVMFlow, ProCAST, CSS PoligonSoft та ін.), які дозволяють одержати розподіл теплових полів у виливку. Аналіз теплових полів дозволяє отримати достовірну інформацію про розташування теплових вузлів, областей 3 недостатньою або надмірною динамікою затвердіння, але при цьому розрахунок усадкової раковини та макрошпаристості проводиться на підставі критеріальних

(C) Селівьорстова Т.В., Селівьорстов В.Ю., 2019 
оцінок [1]. Слід зазначити, що перераховані вище програмні комплекси реалізують широкий спектр специфічних ливарних технологій, таких як безперервне лиття, відцентрове лиття, лиття за витоплюваними моделями, але не дозволяють достатньо коректно враховувати можливість застосування регульованого газового тиску $[2,3]$ на систему виливок-форма.

Шпаристість $є$ одним з основних дефектів виливків, що призводить до зниження механічних властивостей. Даний дефект виникає в результаті недостатнього або утрудненого живлення двофазної зони, тому актуальною проблемою $\epsilon$ розробка математичних моделей формування двофазної зони виливків, що тверднуть в умовах наростаючого газового тиску, зокрема виливків із алюмінієвих сплавів евтектичного складу, що є одними з найпоширеніших для виготовлення фасонного литва.

\section{Фізичні аспекти живлення двофазної зони в металах}

Як відомо, для більшості металів і сплавів характерна наявність температурного інтервалу затвердіння, викликаного наявністю в розплаві фаз із різною температурою затвердіння. Окрім того, фізичні властивості реальних металів і сплавів істотно залежать від температури, зниження якої призводить до усадки сплаву як в рідкому, так і в затверділому стані. Зменшення об'єму в процесі затвердіння повинне компенсуватися розплавом, тобто повинно здійснюватися живлення двофазної зони. У випадку утруднення живлення двофазної зони в кінцевому рахунку утвориться локальна шраристість. Так само, локальне зниження тиску призводить до газової сегрегації та утворення пор (рисунок 1$)$.

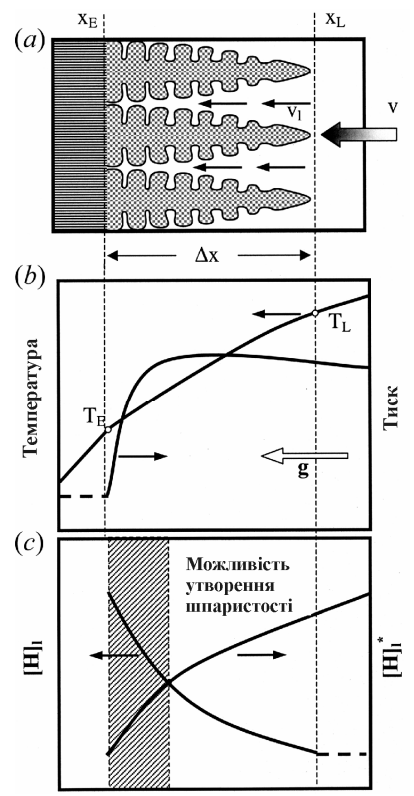

Рисунок 1 -Схематичне зображення (a) 1-D двохфазної зони; (b) профілі температури і тиску (гравітація $g$ направлена вліво); (c) концентрація газу, $[H]_{1}$, межа розчинності газу в рідині, $[H]_{1}^{*}\left(T, \rho, c_{1}\right)[4]$

Крім того, під час затвердіння відбувається відвід газу на межі розділу твердої та рідкої фаз, що призводить до збільшення концентрації газу в розплаві. При досягненні концентрацією критичного значення, яке залежіть від межі розчинності газу в рідини, 
пори можуть утворюватися і рости. Таким чином, інформація про динаміку розвитку шпаристості залежно від параметрів сплаву та конкретних умов затвердіння, що обумовлені ливарною технологією, дозволяє істотно скоротити утворення дефектів виливків, викликаних шпаристістю.

\section{Математична модель живлення двофазної зони металевих виливків, що тверднуть під впливом регульованого газового тиску}

Затвердіння металів і сплавів супроводжується складними фізико-хімічними процесами, що протікають у розплаві. Найбільш важливі 3 них обумовлені: виділенням тепла при фазовому переході; переносом тепла за рахунок конвективних потоків у рідкій фазі; складністю реальних граничних умов теплообміну; неоднорідністю властивостей сплаву; залежністю теплофізичних параметрів від температури; складністю геометрії виливка. У роботах [5 - 7] наведений опис клинноавтоматної математичної моделі для опису металургійних процесів 3 фазовими переходами, що забезпечує коректне врахування термодинамічних властивостей матеріалів. Також запропоновані та досліджені клітинно-автоматні правила для опису фазового переходу в сплавах 3 рухливим фронтом затвердіння, у бінарних квазірівноважних сплавах і сплавах зі складною структурою фазового переходу [7]. Дана термодинамічна клітинно-автоматна модель дозволяє однозначно визначати стан розплаву і його температуру в межах двофазної зони.

Розглянемо процес живлення двофазної зони на макрорівні. На рисунку 2 наведена одномірна модель живлення локальних об’ємів у процесі затвердіння.

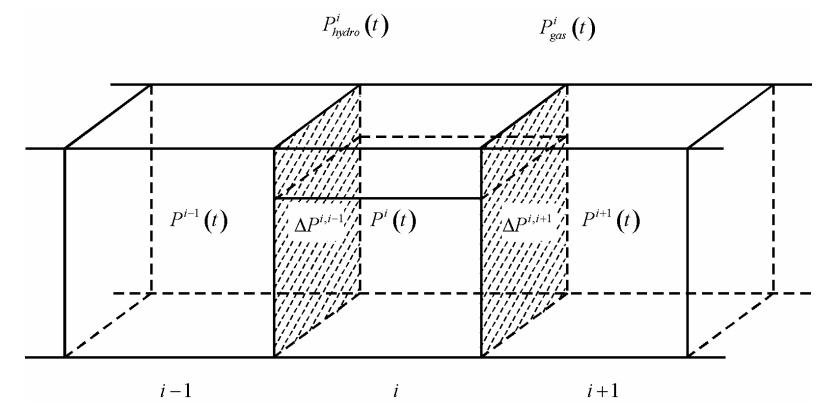

Рисунок 2 - 1-D модель живлення елементарних об’ємів двохфазної зони

Як відомо, у більшості металів і сплавів теплофізичні параметри істотно залежать від температури. Наприклад, щільність і коефіцієнт теплопровідності менші для рідкого стану, а питома теплоємність - більша.

У процесі усадки металу при затвердінні локальний об’єм $i$ виявляється не повністю заповненим через збільшення щільності при зменшенні температури. У зв'язку 3 цим, важливою задачею $є$ визначення кількості металу, що здатний забезпечити живлення даного локального об’єму. Об’єм живлення дорівнює

$$
\begin{gathered}
V^{i}(t)=\frac{m_{V}{ }^{i}}{\rho^{i}\left(T^{i}(t)\right)}, \\
V^{i}(t-1)=\frac{m_{V}{ }^{i}}{\rho^{i}\left(T^{i}(t-1)\right)},
\end{gathered}
$$




$$
\Delta V^{i}(t)=\frac{m_{V}{ }^{i}}{\rho^{i}\left(T^{i}(t)\right)}-\frac{m_{V}{ }^{i}}{\rho^{i}\left(T^{i}(t-1)\right)}=m_{V}{ }^{i}\left(\frac{1}{\rho^{i}\left(T^{i}(t)\right)}-\frac{1}{\rho^{i}\left(T^{i}(t-1)\right)}\right),
$$

де $V^{i}(t)$ - об'єм, $m_{V}{ }^{i}$ - маса, $\rho^{i}\left(T^{i}(t)\right)$ - щільність, $T^{i}(t)$ - температура $i$-го локального об'єму в момент часу $t$.

Будемо розглядати процес живлення $i$-го локального об’єму в ізотермічному наближенні. Визначимо тиск живлення $P_{\text {supply }}$ для $i$-го локального об’єму.

$$
\begin{gathered}
P^{i}(t) V^{i}(t)=P^{i}(t-1) V^{i}(t-1), \\
P^{i}(t)=\frac{P^{i}(t-1) V^{i}(t-1)}{V^{i}(t)},
\end{gathered}
$$

Локальні об’єми в процесі живлення двофазної зони піддаються дії тиску гідростатичного напору $P_{h y d r o}$ і впливу регульованого газового тиску $P_{g a s}$.

$$
\begin{gathered}
P^{i}(t-1)=P_{\text {hydro }}^{i}(t-1)+P_{\text {gas }}^{i}(t-1), \\
P^{i}(t)=P_{\text {hydro }}^{i}(t)+P_{\text {gas }}^{i}(t)+P_{\text {supply }}^{i}(t) .
\end{gathered}
$$

Підставимо (6), (7) в (5) і одержимо співвідношення для $P_{\text {supply }}(t)$.

$$
\begin{aligned}
& P_{\text {hydro }}^{i}(t)+P_{\text {gas }}^{i}(t)+P_{\text {supply }}^{i}(t)=\frac{\left(P_{\text {hydro }}^{i}(t-1)+P_{\text {gas }}^{i}(t-1)\right) \frac{m_{V}{ }^{i}}{\rho^{i}\left(T^{i}(t-1)\right)}}{\frac{m_{V}{ }^{i}}{\rho^{i}\left(T^{i}(t)\right)}} \\
& =\left(P_{\text {hydro }}^{i}(t-1)+P_{\text {gas }}^{i}(t-1)\right) \frac{\rho^{i}\left(T^{i}(t)\right)}{\rho^{i}\left(T^{i}(t-1)\right)}, \\
& P_{\text {supply }}^{i}(t)=\left(P_{\text {hydro }}^{i}(t-1)+P_{\text {gas }}^{i}(t-1)\right) \frac{\rho^{i}\left(T^{i}(t)\right)}{\rho^{i}\left(T^{i}(t-1)\right)}-\left(P_{\text {hydro }}^{i}(t)+P_{\text {gas }}^{i}(t)\right) .
\end{aligned}
$$

Кількість речовини $\Delta m^{i}$, що надійде через поверхню контакту $i$-го локального об'єму за час $\Delta t$ знаходимо з співвідношення

$$
\Delta m^{i}=\left(P^{i-1}(t)-P^{i}(t)\right) \frac{s^{i-1, i}{ }_{\text {unit }}}{v^{i-1, i}} \Delta t+\left(P^{i}(t)-P^{i+1}(t)\right) \frac{s^{i, i+1}{ }_{\text {unit }}}{v^{i, i+1}} \Delta t,
$$

де $s_{u n i t}^{i-1, i}, s_{u n i t}^{i, i+1}-$ площі контакту одиничних об’ємів, $v^{i-1, i}, v^{i, i+1}-$ швидкість протікання рідини крізь зони контакту

$$
\begin{aligned}
& v^{i-1, i}=\frac{1}{\eta^{i-1, i}\left(T^{i}(t)\right)} \frac{P_{\text {supply }}^{i}(t) s_{\text {supply }}^{i-1, i}}{l_{\text {supply }}^{i}}, \\
& v^{i, i+1}=\frac{1}{\eta^{i, i+1}\left(T^{i}(t)\right)} \frac{P_{\text {supply }}^{i}(t) s_{\text {supply }}^{i, i+1}}{l_{\text {supply }}^{i}},
\end{aligned}
$$


де $\eta^{i-1, i}\left(T^{i}(t)\right), \eta^{i, i+1}\left(T^{i}(t)\right)$ - кінематична в'язкість у зоні контакту одиничних об'ємів, $s_{\text {supply }}^{i-1, i}, s_{\text {supply }}^{i, i+1}$ - площа зони контакту, через яку здійснюється живлення $i$-го локального об’єму, $l_{\text {supply }}^{i}$ - довжина зони живлення в одиничному об’ємі. Вираз (9) з використанням (10) і (11) має вигляд

$$
\begin{aligned}
& \Delta m^{i}=\left(P^{i-1}(t)-P^{i}(t)\right) s_{\text {unit }}^{i-1, i} \frac{\eta^{i-1, i}\left(T^{i}(t)\right) l_{\text {supply }}^{i}}{P_{\text {supply }}^{i}(t) s_{\text {supply }}^{i-1, i}} \Delta t+ \\
& +\left(P^{i}(t)-P^{i+1}(t)\right) s_{\text {unit }}^{i, i+1} \frac{\eta^{i, i+1}\left(T^{i}(t)\right) l_{\text {supply }}^{i}}{P_{\text {supply }}^{i}(t) s_{\text {supply }}^{i, i+1}} \Delta t .
\end{aligned}
$$

У формулі (12) співвідношення $s_{\text {supply }}^{i-1, i} / s_{\text {unit }}^{i-1, i}$ i $s_{\text {supply }}^{i, i+1} / s_{u n i t}^{i, i+1} \in$ оцінкою частки площі крізь яку здійснюється живлення $i$-го локального об'єму. Довжину зони живлення в

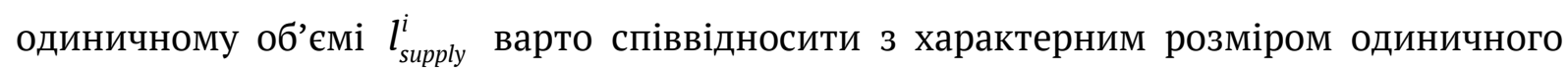
об'єму. При розрахунку $\Delta m^{i}$ важливо враховувати умову не перевищення даного значення понад необхідне $\Delta m^{i}=\Delta V^{i}(t) \rho^{i}\left(T^{i}(t)\right)$.

Варто зазначити, що при моделюванні процесів живлення в якості параметру розплаву, що характеризує здатність заповнювати локальний об’єм, використовують величину плинності розплаву. Ця величина зворотна в'язкості та має розмірність $1 /($ Па·c $)$. Вираз для швидкості живлення в цьому випадку прийме вигляд

$$
\begin{aligned}
& v^{i-1, i}=\sigma^{i-1, i}\left(T^{i}(t)\right) \frac{P_{\text {supply }}^{i}(t) s_{\text {supply }}^{i-1, i}}{l_{\text {supply }}^{i}}, \\
& v^{i, i+1}=\sigma^{i, i+1}\left(T^{i}(t)\right) \frac{P_{\text {supply }}^{i}(t) s_{\text {supply }}^{i, i+1}}{l_{\text {supply }}^{i}},
\end{aligned}
$$

де $\sigma^{i-1, i}\left(T^{i}(t)\right), \sigma^{i, i+1}\left(T^{i}(t)\right)$ - плинність розплаву в зоні живлення одиничного об'єму.

На рисунку 3 показана прийнята розрахункова схема живлення локального об'єму.

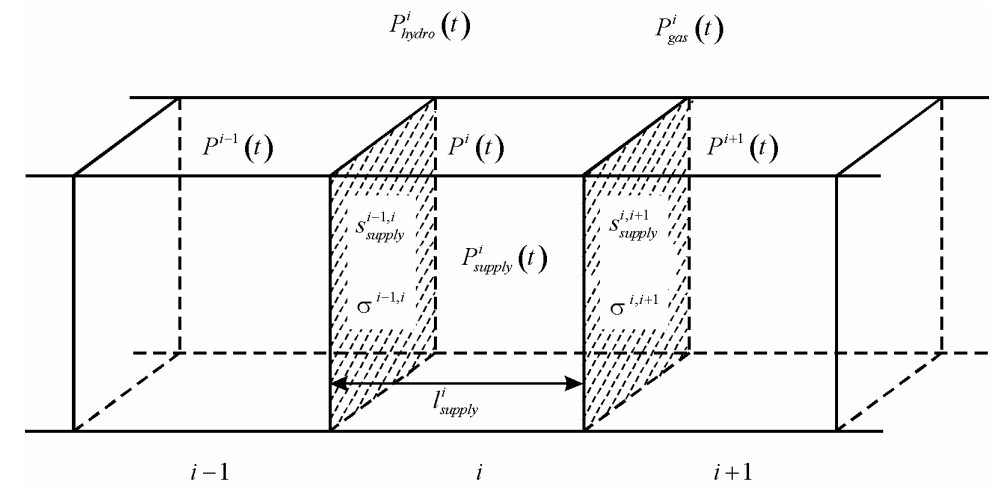

Рисунок 3 -Схема живлення одиничного об’єму 
В цьому випадку маса речовини, що забезпечує живлення одиничного об’єму прийме вигляд

$$
\begin{aligned}
& \Delta m^{i}=\left(P^{i-1}(t)-P^{i}(t)\right) \frac{l_{\text {supply }}^{i}}{\sigma^{i-1, i}\left(T^{i}(t)\right) P_{\text {supply }}^{i}(t) s_{\text {effect }}^{i-1, i}} \Delta t+ \\
& +\left(P^{i}(t)-P^{i+1}(t)\right) \frac{l_{\text {supply }}^{i}}{\sigma^{i, i+1}\left(T^{i}(t)\right) P_{\text {supply }}^{i}(t) s_{\text {effect }}^{i, i+1}} \Delta t= \\
& =\frac{l_{\text {supply }}^{i}}{P_{\text {supply }}^{i}(t)} \Delta t\left(\begin{array}{c}
\left(P^{i-1}(t)-P^{i}(t)\right) \frac{1}{\sigma^{i-1, i}\left(T^{i}(t)\right) s_{\text {effect }}^{i-1, i}}+ \\
+\left(P^{i}(t)-P^{i+1}(t)\right) \frac{1}{\sigma^{i, i+1}\left(T^{i}(t)\right) s_{\text {effect }}^{i, i+1}}
\end{array}\right),
\end{aligned}
$$

де $s_{\text {effect }}^{i-1, i}=s_{\text {supply }}^{i-1, i} / s_{\text {unit }}^{i-1, i}, s_{\text {effect }}^{i, i+1}=s_{\text {supply }}^{i, i+1} / s_{\text {unit }}^{i, i+1}-$ ефективна площа, через яку забезпечується живлення $i$-го локального об’єму з боку $i-1$ та $i+1$ локальних об’ємів.

Таким чином, реалізація математичної моделі живлення двофазної зони в процесі затвердіння в умовах регульованого газового тиску припускає завдання початкових і граничних умов для температури і тиску, а також режиму зміни газового тиску. При цьому на кожній ітерації виконується наступна послідовність обчислень: температура $[5,6,7], P_{\text {supply }}^{i}(t)(8)$ і $P^{i}(t)(7), \Delta m^{i}$ (15) та внесення корегувань в теплову задачу.

Граничну кількість речовини, що є необхідною для заповнення об’єму $\Delta V^{i}(t)$ знаходимо із співвідношення (16)

$$
\begin{gathered}
\frac{m^{i}(t)}{\rho^{i}\left(T^{i}(t)\right)}=\frac{m^{i}(t-1)}{\rho^{i}\left(T^{i}(t-1)\right)}, \\
\frac{m^{i}(t-1)+\Delta m^{i}}{\rho^{i}\left(T^{i}(t)\right)}=\frac{m^{i}(t-1)}{\rho^{i}\left(T^{i}(t-1)\right)}, \\
\Delta m^{i}=m^{i}(t-1) \frac{\rho^{i}\left(T^{i}(t)\right)}{\rho^{i}\left(T^{i}(t-1)\right)}-m^{i}(t-1), \\
\Delta m^{i}=m^{i}(t-1)\left(\frac{\rho^{i}\left(T^{i}(t)\right)}{\rho^{i}\left(T^{i}(t-1)\right)}-1\right) .
\end{gathered}
$$

\section{Результати моделювання процесу живлення двохфазної зони}

виливку з алюмінієвого сплаву евтектичного складу

Розглянемо модельну задачу живлення двофазної зони виливку з алюмінієвого сплаву евтектичного складу. У таблиці I наведені термодинамічні параметри алюмінієвого сплаву евтектичного складу. 
Таблиця 1

Теплофізичні параметри алюмінієвого сплаву *

\begin{tabular}{|c|c|c|}
\hline Теплофізичні параметр & Солідус & Ліквідус \\
\hline Щільність, $к 2 / M^{3}$ & 25000 & 2200 \\
\hline Питома теплоємність, Дж/кг K & 1100 & 1280 \\
\hline Коефіцієнт теплопровідності, $\mathrm{Bm} / \mathrm{M} \mathrm{K}$ & 170 & 170 \\
\hline
\end{tabular}

Температура фазового переходу $T_{f}=580^{\circ} \mathrm{C}$, прихована теплота фазового переходу $L=370 \kappa Д ж / \kappa 2$.

* Довідкова система САМ ЛП "ПОЛІГОН" (С)

На рисунку 4 наведена схема розрахункової задачі.

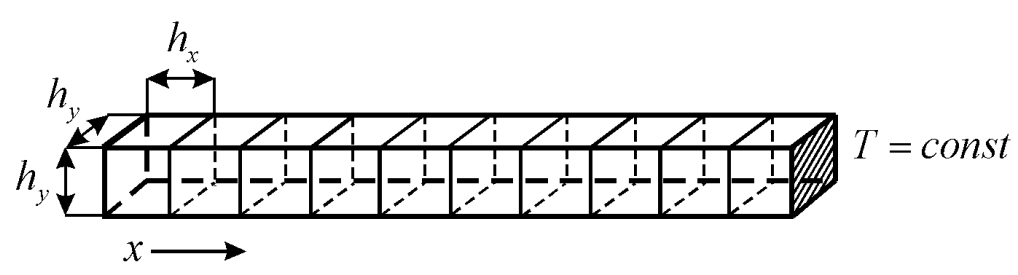

Рисунок 4 - Розрахункова задача

На рисунках 5 - 7 показаний результат розрахунку розподілу температури (рисунок 5), кількості рідкої фази (рисунок 6) і частки заповненого локального об'єму (рисунок 7). Сімейство кривих відображає динаміку протікання термодинамічного процесу живлення двофазної зони в умовах регульованого газового тиску.

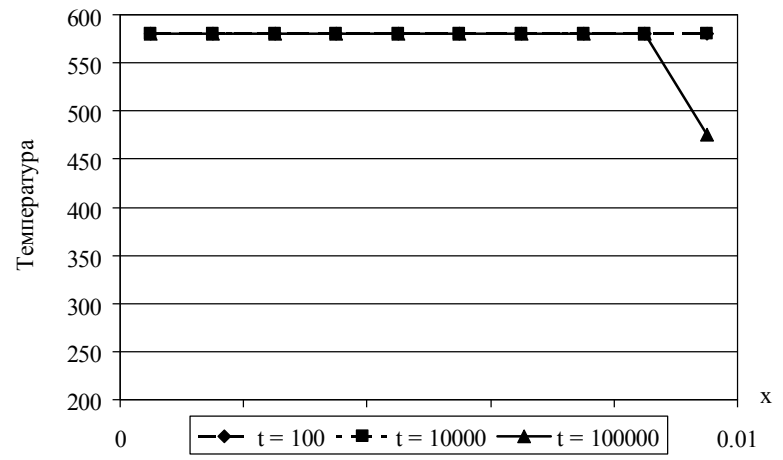

Рисунок 5 - Розподіл температури

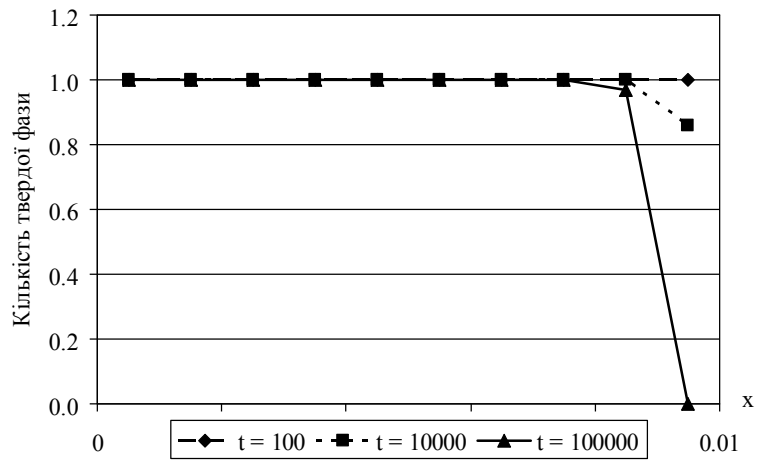

Рисунок 6 - Розподіл

кількості рідкої фази

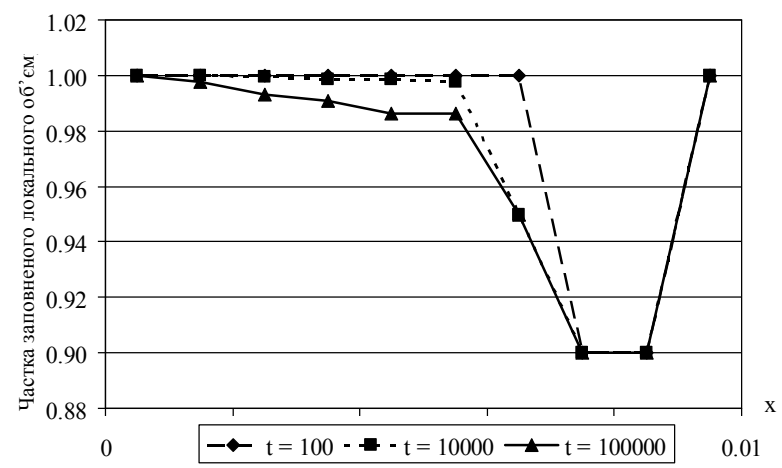

Рисунок 7 - Частка заповнення локального об’єму 
Рисунок 7 безпосередньо відображає процес живлення двофазної зони виливку алюмінієвого сплаву евтектичного складу.

\section{Висновки}

У статті наведені фізичні аспекти процесу живлення двофазної зони при затвердінні металів і сплавів. Запропонована математична модель живлення двофазної зони металевих виливків, що твердіють під впливом регульованого газового тиску базується на термодинамічній клітинно-автоматній математичній моделі для опису металургійних процесів з фазовими переходами, що забезпечує коректний облік зміни термодинамічних характеристик металів при затвердінні. Модель живлення двофазної зони дозволяє забезпечити коректне врахування регульованого газового тиску в системі виливок-форма й може бути масштабована на двомірний, тривимірний простір. Наведені результати моделювання процесу живлення двохфазної зони виливку з алюмінієвого сплаву евтектичного складу.

\section{ЛITEPАТУРА}

1. Selivyorstova T., Mikhalyov A. Analysis of Prediction Mathematical Models of Shrinkage Defects in Castings // 2018 IEEE First International Conference on System Analysis \& Intelligent Computing (SAIC). (8-12 Oct. 2018). - Kiev, Ukraine: IEEE, 2018, Page(s):1 - 5/ DOI: 10.1109/SAIC.2018.8516811.

2. Селиверстов В.Ю. Технология газодинамического воздействия на расплав в литейной форме - один из перспективных способов повышения качества металла отливок /В.Ю. Селиверстов //Сучасні проблеми металургії. Наукові праці. - 2007. Tом 10. - С. $25-35$.

3. Пат. 28858 Україна, МПК (2006) B22D 18/00. Спосіб отримання виливків /Селівьорстов В.Ю., Хричиков В.Є., Доценко Ю.В.; власник патенту Селівьорстов В.Ю. № 200708968; заявл. 03.08.2007; опубл. 25.12.2007, Бюл. № 21.

4. Ch. Pequet, M. Rappaz, M. Gremaud Modeling of microporosity, macroporosity, and pipeshrinkage formation during the solidification of alloys using a mushy-zone refinement method: Applications to aluminum alloys // Metallurgical and Materials Transactions A. July 2002, Volume 33, Issue 7, pp 2095-2106.

5. Михайловская Т.В. Трехмерная клеточно-автоматная модель процесса затвердевания металлов и сплавов / Т.В. Михайловская, А.И. Михалев // Сучасні проблеми металургії. Наукові праці. 2006. - Том 9. - С. 102 - 112.

6. Михайловская Т.В. Применение клеточных автоматов для математического моделирования фазового перехода в эвтектических сплавах / Т.В. Михайловская // Системные технологии. Региональный межвузовский сборник научных трудов. 2007. Выпуск 5 (53). - С. 162 - 170.

7. Михайловская Т.В., Михалев А.И., Гуда А.И. Исследование правил клеточных автоматов для моделирования процессов затвердевания квазиравновесных бинарных сплавов // ААЭКС, 2008, №2. с. 19 - 27. 


\section{REFFERENCES}

1. Selivyorstova T., Mikhalyov A. Analysis of Prediction Mathematical Models of Shrinkage Defects in Castings // 2018 IEEE First International Conference on System Analysis \& Intelligent Computing (SAIC). (8-12 Oct. 2018). - Kiev, Ukraine: IEEE, 2018, Page(s):1 - 5/ DOI: $10.1109 /$ SAIC.2018.8516811.

2. Seliverstov V.Yu. Tehnologiya gazodinamicheskogo vozdeystviya na rasplav v liteynoy forme - odin iz perspektivnyih sposobov povyisheniya kachestva metalla otlivok /V.Yu. Seliverstov // Suchasni problemy metalurhii. Naukovi pratsi. - 2007. - Tom 10. - S. 25 - 35.

3. Pat. 28858 Ukraina, MPK (2006) V22D 18/00. Sposib otrymannia vylyvkiv /Selivorstov V.Iu., Khrychykov V.Ie., Dotsenko Yu.V.; vlasnyk patentu Selivorstov V.Iu. - № 200708968; zaiavl. 03.08.2007; opubl. 25.12.2007, Biul. № 21.

4. Ch. Pequet, M. Rappaz, M. Gremaud Modeling of microporosity, macroporosity, and pipeshrinkage formation during the solidification of alloys using a mushy-zone refinement method: Applications to aluminum alloys // Metallurgical and Materials Transactions A. July 2002, Volume 33, Issue 7, pp 2095-2106.

5. Mihaylovskaya T.V. Trehmernaya kletochno-avtomatnaya model protsessa zatverdevaniya metallov i splavov / T.V. Mihaylovskaya, A.I. Mihalev // Suchasni problemy metalurhii. Naukovi pratsi. 2006. - Tom 9. - S. 102 - 112.

6. Mihaylovskaya T.V. Primenenie kletochnyih avtomatov dlya matematicheskogo modelirovaniya fazovogo perehoda $\mathrm{v}$ evtekticheskih splavah / T.V. Mihaylovskaya // Sistemnyie tehnologii. Regionalnyiy mezhvuzovskiy sbornik nauchnyih trudov. 2007. Vyipusk 5 (53). - S. 162 - 170.

7. Mihaylovskaya T.V., Mihalev A.I., Guda A.I. Issledovanie pravil kletochnyih avtomatov dlya modelirovaniya protsessov zatverdevaniya kvaziravnovesnyih binarnyih splavov // AAEKS, 2008, \#2. s. 19 - 27.

Received 22.01.19

\section{MATHEMATICAL MODEL OF FORMATION OF TWO-PHASE ZONE OF CASTING OF ALUMINUM ALLOY OF EUTECTIC COMPOSITION, WHICH IS HARDENED UNDER INCREASING GAS PRESSURE}

Analysis of thermal fields allows to obtain reliable information about the location of thermal nodes, areas with insufficient or excessive dynamics of solidification, but the calculation of the shrinkage shell and macrosparity is carried out on the basis of criterion assessments. Porosity is one of the main defects of castings, which leads to a decrease in mechanical properties. This defect arises as a result of insufficient or difficult supply of the two-phase zone; therefore, an urgent problem is the development of mathematical models for the formation of a two-phase zone of castings hardening under conditions of increasing gas pressure, in particular, casting from aluminum alloys of eutectic composition, are among the most common for the manufacture of shaped castings. The proposed mathematical model for supplying a two-phase zone of metal castings hardening under the influence of controlled gas pressure is based on a thermodynamic cell-automatic mathematical model for describing metallurgical processes with phase transitions, ensures that the changes in the thermodynamic characteristics of metals correctly take place. The power supply model of the two-phase zone allows to provide a correct account of the adjustable gas pressure in the 
casting-form system and can be scaled to two-dimensional and three-dimensional space. The results of modeling the process of feeding the two-phase zone of the casting of aluminum alloy of eutectic composition. The dependences of the amount of the liquid phase in local volumes in the two-phase zone.

Keywords: mathematical model, heat transfer, mass transfer, filtration, shrinkage, saliva, aluminum, eutectic composition.

\section{МАТЕМАТИЧЕСКАЯ МОДЕЛЬ ФОРМИРОВАНИЯ ДВУХФАЗНОЙ ЗОНЫ ОТЛИВКИ ИЗ АЛЮМИНИЕВОГО СПЛАВА ЭВТЕКТИЧЕСКОГО СОСТАВА, ЗАТВЕРДЕВАЕТ ПРИ НАРАСТАЮЩЕМ ГАЗОВОМ ДАВЛЕНИЯ}

Анализ тепловых полей позволяет получить достоверную информацию о расположении тепловых узлов, областей с недостаточной или избыточной динамикой затвердевания, но при этом расчет усадочной раковины и макрошпаристости проводится на основании критериальных оценок. Пористость является одним из основных дефектов отливок, что приводит к снижению механических свойств. Данный дефект возникает в результате недостаточного или затрудненного питания двухфазной зоны, поэтому актуальной проблемой является разработка математических моделей формирования двухфазной зоны отливок, затвердевающих в условиях нарастающего газового давления, в частности отливки из алюминиевых сплавов эвтектического состава, являются одними из самых распространенных для изготовления фасонного литья. Предложенная математическая модель питания двухфазной зоны металлических отливок, затвердевающих под воздействием регулируемого газового давления базируется на термодинамической клеточноавтоматной математической модели для описания металлургических процессов с фазовыми переходами, обеспечивает корректный учет изменения термодинамических характеристик металлов при затвердевании. Модель питания двухфазной зоны позволяет обеспечить корректній учет регулируемого газового давления в системе отливка-форма и может быть масштабирована на двухмерное и трехмерное пространства. Приведенные результаты моделирования процесса питания двухфазной зоны отливки из алюминиевого сплава эвтектического состава. Полученные зависимости количества жидкой фазы в локальных объемах в двухфазной зоны.

Ключевые слова: математическая модель, теплоперенос, массоперенос, фильтрация, усадка, алюминиевый сплав, эвтектика.

Селівьорстова Тетяна Віталіївна - к.т.н., доцент, кафедра інформаційних технологій та систем, Національна металургійна академія України.

Selivorstova Tatyana - Candidate of Technical Sciences, Associate Professor, Department of Information Technologies and Systems, The National Metallurgical Academy of Ukraine.

Селівьорстов Вадим Юрійович - д.т.н., професор, професор кафедри ливарного виробництва, Національна металургійна академія України.

Selivorstov Vadim - Doctor of Technical Sciences, Professor, Professor of the Department of Foundry, National Metallurgical Academy of Ukraine. 